\title{
URGENSI KURSUS PRA NIKAH DALAM MEMBENTUK KELUARGA DI ERA MODERN
}

\author{
Mughni Labib Ilhamuddin Is Ashidiqie \\ Universitas Islam Negeri Sunan Kalijaga \\ Email: mughnilabibbb@gmail.com \\ DOI: $10.37876 /$ adhki.v2i2.40
}

\begin{abstract}
This article elaborates the urgency of pre-marital courses as an effort to build a family in the modern era. The very reason is that, at present, family is one of the keys to achieving national development success. In assessing the urgency of the pre-marital course, the researcher used a normative juridical approach by tracing the rules regarding pre-marital course and family development, as well as other literature related to the topic under discussion. This research was analytical descriptive, aiming to describe and analyze the overall object under research. the research result indicates that families in the modern era play a very important role to achieve national development success as one of the issues in national development is family. Therefore, building a prosperous family life is a necessity. One of the efforts to achieve said objective is by holding pre-marital courses. Moreover, judging from the subjects in pre-marital courses, pre-marital courses have a relevance to national development through building resilient families. However, the researcher found that there was a subject that had not been explicitly stated in the courses, namely gender partnerships. Therefore, it is needed to add to the courses as in the context of building resilient families, one of the variables is gender partnership.
\end{abstract}

Keywords: Pre-Marital Course, Building Family, National Development.

\begin{abstract}
Abstrak
Artikel ini menjelaskan tentang urgensi kursus pra nikah sebagai upaya membentuk keluarga di era modern. Hal ini disebabkan, saat ini keluarga menjadi salah satu kunci untuk mencapai keberhasilan pembangunan nasional. Dalam mengkaji urgensi kursus pra nikah tersebut penulis menggunakan pendekatan yuridis normatif, yaitu menelusuri peraturan-peratuan tentang kursus pra nikah dan pembangunan keluarga serta literatur-literatur lainnya yang berkaitan dengan pembahasan yang penulis kaji. Jenis penelitian ini bersifat deskriptif analitis, yang bertujuan untuk menggambarkan secara keseluruhan objek yang diteliti dan kemudian dianalisis. Adapun hasil penelitian ini menunjukkan bahwa keluarga di era modern memiliki peran yang sangat penting untuk mencapai keberhasilan pembangunan nasional, sebab, dalam pembangunan nasional tersebut salah satu yang menjadi isunya adalah keluarga. Karenanya, menciptakan kehidupan keluarga yang sejahtera merupakan suatu keniscayaan yang harus dilakukan, salah satu upayanya dapat dilakukan dengan menyelenggarakan kursus pra nikah. Selain itu, dilihat dari materi yang ada dalam kursus pra nikah, maka kursus pra nikah ini memiliki relevansinya dengan pembangunan nasional melalui pembangunan ketahanan keluarga. Namun, penulis menemukan bahwa terdapat materi yang belum dicantumkan secara eksplisit, yaitu materi tentang kemitraan gender. Oleh karenanya, diperlukan penambahan materi tentang kemitraan gender, sebab dalam dalam rangka pembangunan ketahanan keluarga tersebut salah satu variabelnya adalah kemitraan gender.
\end{abstract}

Kata Kunci: Kursus Pra Nikah, Pembangunan Keluarga, Pembangunan Nasional. 


\section{Pendahuluan}

Sebagai institusi terkecil dari masyarakat yang dapat menjadi penentu kualitas baik buruknya generasi masa depan, keluarga merupakan pondasi awal untuk membangun karakter bangsa. Kegagalan dalam membangun kesejahteraan keluarga dapat menjadi ancaman terhadap pembangunan manusia secara keseluruhan. Hal ini mengindikasikan bahwa untuk membentuk kualitas masa depan bangsa, dapat dimulai dengan menciptakan kesejahteraan dalam kehidupan keluarga. Sebagaimana dalam pembangunan nasional, keluarga menjadi salah satu isunya.

Dalam rangka pembangunan nasional, salah satu isu krusial yang menjadi kunci bagi keberhasilan pembangunan tersebut adalah keluarga, sebagaimana disebutkan dalam Peraturan Pemerintah (PP) Republik Indonesia Nomor 21 Tahun 1994 tentang Penyelenggaraan Pembangunan Keluarga Sejahtera. Dalam PP tersebut secara eksplisit dipaparkan, bahwa keluarga sebagai unit terkecil dalam masyarakat mempunyai peran yang penting dalam pembangunan nasional, oleh karena itu perlu dibina dan dikembangkan kualitasnya agar senantiasa dapat menjadi keluarga sejahtera serta menjadi sumber daya manusia yang efektif bagi pembangunan nasional. ${ }^{1}$ Selain itu, dijelaskan juga dalam Undang-Undang (UU) Republik Indonesia Nomor 52 Tahun 2009 Pasal 4 Ayat (2) tentang Perkembangan Kependudukan dan Pembangunan Keluarga dinyatakan bahwa, pembangunan keluarga bertujuan untuk meningkatkan kualitas keluarga agar dapat timbul rasa aman, tentram dan harapan masa depan yang lebih baik dalam mewujudkan kesejahteraan lahir dan kebahagiaan batin. $^{2}$

Berdasarkan peraturan perundang-undangan di atas, penulis melihat bahwa saat ini kesejahteraan dalam kehidupan keluarga merupakan suatu keniscayaan yang harus diciptakan keberadaanya. Karena, untuk mencapai keberhasilan pembangunan nasional salah satu indikatornya sangat terkait terhadap faktor manusia yang dalam institusi keluarga. Dengan demikian, untuk membentuk keluarga di era modern saat ini, maka diperlukan pembekalan pengetahuan terkait dengan kehidupan keluarga, baik secara fisik yaitu persiapan yang berhubungan dengan pengetahuan dan kesehatan, maupun secara mental yaitu terkait dengan psikologis dan kedewasaan dalam berfikir. Hal ini penting, karena setelah menikah akan terjalin suatu komitmen serta tanggung jawab antara istri-suami. Disamping itu, dalam berkeluarga istri dan suami juga harus mampu menghadapi masalah-masalah yang akan menimpanya dan mengelola konflik yang akan terjadi.

\footnotetext{
1 Peraturan Pemerintah Republik Indonesia Nomor 21 Tahun 1994 tentang Penyelenggaraan Pembangunan Keluarga Sejahtera.

2 Pasal 4 Ayat (2) Undang-Undang Republik Indonesia Nomor 52 Tahun 2009 tentang Perkembangan Kependudukan dan Pembangunan Keluarga.
} 
Pembekalan tersebut, dapat dilaksanakan melalui kursus pra nikah yang diselenggarakan oleh lembaga terkait. Sebagaimana maksud dari tujuan kursus pra nikah itu sendiri, yaitu untuk memberikan bekal pengetahuan, pemahaman, keterampilan dan penumbuhan kesadaran kepada remaja usia nikah tentang kehidupan rumah tangga dan keluarga. ${ }^{3}$ Dengan demikian, maksud dari artikel ini membahas peran penting kursus pra nikah sebagai upaya untuk mencapai keberhasilan pembangunan nasional yang salah satunya melalui kesejahteraan dalam kehidupan keluarga.

\section{Eksistensi Kursus Pra Nikah}

Sebagai program yang difokuskan untuk memberi pengetahuan dan pemahaman terhadap persoalan tentang perkawinan dan kehidupan berumah tangga, kursus pra nikah ini dapat diselenggarakan oleh Badan Penasihatan Pembinaan dan Pelestarian Perkawinan (BP4) dan organisasi keagamaan islam lainnya. Lahirnya lembaga tersebut dipicu dari rendahnya kualitas perkawinan umat islam Indonesia, seperti tingginya angka perceraian, maraknya perkawinan usia dini dan poligami tidak sehat atau sewenang-wenang. ${ }^{4}$ Sehingga pemerintah merasa perlu untuk memperhatikan fenomena tersebut dan akhirnya Kementerian Agama mengeluarkan Surat Keputusan Nomor 85 Tahun 1961 untuk menentukan kepengurusan BP4 dan BP4 sebagai badan yang berfokus di bidang peningkatan kualitas perkawinan dan meminimalisir tingkat perceraian. ${ }^{5}$ Karenanya, keberadaan BP4 ini bertujuan untuk meningkatkan kualitas perkawinan, mengupayakan agar para calon pengantin dapat membentuk kehidupan keluarga yang sejahtera dan mencegah perceraian.

Dalam perjalanannya BP4 ini mengalami perkembangan, salah satunya perubahan akronim nama yaitu: Pertama, pada tahun 1960 Badan Penasihat Perkawinan, Perselisihan dan Perceraian. Kedua, tahun 1977 Badan Pembinaan, Penasihatan Perkawinan dan Perselisihan Rumah Tangga. Ketiga, pada Musyawarah Nasional (Munas) XIV Tahun 2009 berubah menjadi Badan Penasihat Pembinaan dan Pelestarian Perkawinan (BP4). Perubahan-perubahan tersebut disebabkan adanya perubahan dan peningkatan dalam persoalan keluarga, sehingga BP4 perlu mengubah atau menambah akronim namanya agar dapat mengakomodir ruang lingkup kerjanya. Adapun ruang lingkup kerjanya, BP4 bermitra dengan

${ }^{3}$ Pasal 1 Ayat (1) Peraturan Direktur Jenderal Bimbingan Masyarakat Islam Nomor: DJ.II/542 Tahun 2013 tentang Pedoman Penyelenggaraan Kursus Pra Nikah.

4 Zakyyah Iskandar, Peran Kursus Pra Nikah Dalam Mempersiapkan Pasangan Suami-Istri Menuju Keluarga Sakinah, Al-Ahwal: Jurnal Hukum Keluarga Islam, Vol. 10, No. 1, Juni 2017, hlm. 89.

${ }^{5}$ Khoiruddin Nasution dan Syamruddin Nasution, Peraturan dan Program Membangun Ketahanan Keluarga: Kajian Sejarah Hukum, Asy-Syir'ah, Vol. 51, No. 1, Juni 2017, hlm. 6. 
Kementerian Agama yang bertugas untuk meningkatkan dan membantu kualitas perkawinan. ${ }^{6}$

Perlunya peningkatan kualitas perkawinan tersebut karena dalam menjalani kehidupan rumah tangga, kualitas sebuah perkawinan nya sangat ditentukan oleh masing-masing calon mempelai. Karenanya, BP4 bertugas untuk memberikan pemahaman seputar kehidupan rumah tangga kepada calon pengantin agar dapat membina keluarga yang sejahtera. Namun, sebelum menyelenggarakan kursus tersebut BP4 terlebih dahulu harus memperoleh Akreditasi dari Kementerian Agama. Adapun dasar mekanismenya, didasarkan pada Peraturan Direktur Jenderal Bimbingan Masyarakat Islam tentang Pedoman Penyelenggaraan Kursus Pra nikah Nomor. DJ. II/542 Tahun 2013 yang telah diperbaharui dari Peraturan Direktur Jenderal Bimbingan Masyarakat Islam tentang Kursus Calon Pengantin Nomor. DJ. II/491 Tahun 2009, dengan adanya pedoman tersebut maka penyelenggaraan kursus pra nikah menjadi jelas. ${ }^{7}$

Pembaharuan tersebut pada dasarnya tidak mengubah esensi dari kursus pra nikah, hanya saja teknis pelaksanaanya yang diubah, hal ini dapat ditemukan dalam pengertian dan maksud dari programnya. Dalam Peraturan Direktur Jenderal Bimbingan Masyarakat Islam tahun 2009 yang dimaksud kursus calon pengantin adalah pemberian bekal pengetahuan, pemahaman dan keterampilan dalam waktu singkat kepada calon pengantin tentang kehidupan rumah tangga. Sedangkan pada Peraturan Direktur Jenderal Bimbingan Masyarakat Islam 2013 kursus pra nikah adalah pemberian bekal pengetahuan, pemahaman, keterampilan dan penumbuhan kesadaran pada remaja usia nikah tentang kehidupan rumah tangga dan keluarga. ${ }^{8}$

Berdasarkan peraturan tersebut, maka penyelenggaraan kursus pra nikah sebagaimana termaktub dalam Pasal 3 Ayat (1) Peraturan Direktur Jenderal Bimbingan Masyarakat Islam 2013 tentang Pedoman Kursus Pra Nikah dapat dilakukan oleh BP4 atau lembaga/organisasi keagamaan Islam lainnya yang telah mendapat akreditasi dari Kementerian Agama. ${ }^{9}$ Atas dasar itu, maka masyarakat diberikan kesempatan agar dapat berpartisipasi dalam rangka membangun serta membina keluarga, mencegah terjadinya kekerasan dalam rumah tangga dan perceraian. ${ }^{10}$ Sedangkan dasar hukum penyelenggaraanya, sebagai berikut:

${ }^{6}$ Ibid, hlm. 5.

7 Afrizal, Implementasi Kursus Pra Nikah dalam Mengurangi Angka Perceraian di KUA Pringsewu, Ijtimaiyyah: Jurnal Pengembangan Masyarakat Islam, Vol. 10, No. 1, Mei 2017, hlm. 101.

${ }^{8}$ Zakyyah Iskandar, Peran, hlm. 89.

9 Pasal 3 Ayat (1) Peraturan Direktur Jenderal Bimbingan Masyarakat Islam Nomor: DJ.II/542 Tahun 2013 tentang Pedoman Penyelenggaraan Kursus Pra Nikah.

${ }^{10}$ Bab III Peraturan Direktur Jenderal Bimbingan Masyarakat Islam Nomor: DJ.II/542 Tahun 2013 tentang Pedoman Penyelenggaraan Kursus Pra Nikah. 
1. Undang-Undang Nomor 1 Tahun 1974 tentang Perkawinan (Lembaran Negara Republik Indonesia Tahun 1974 Nomor 1, Tambahan Lembaran Negara Republik Indonesia Nomor 2019);

2. Undang-Undang Nomor 10 Tahun 1992 tentang Perkembangan Kependudukan dan Perkembangan Keluarga Sejahtera;

3. Undang-Undang Nomor 23 Tahun 2002 tentang Perlindungan Anak (Lembaran Negara Republik Indonesia Tahun 2002 Nomor 109, Tambahan Lembaran Negara Republik Indonesia Nomor 4235);

4. Undang-Undang Nomor 23 Tahun 2004 tentang Penghapusan Kekerasan Dalam Rumah Tangga (Lembaran Negara Republik Indonesia Tahun 2004 Nomor 95, Tambahan Lembaran Negara Republik Indonesia 4419);

5. Instruksi Presiden Nomor 9 Tahun 2000 tentang Pengarusutamaan Gender dalam Pembangunan Nasional;

6. Keputusan Presiden Republik Indonesia Nomor 8 Tahun 2002 tentang Rencana Aksi Nasional Penghapusan Perdagangan Perempuan dan Anak;

7. Peraturan Presiden Nomor 20 Tahun 2008 tentang Perubahan keempat Atas Peraturan Presiden Nomor 9 Tahun 2005 tentang Kedudukan, Tugas, Fungsi, Susunan Organisasi dan Tata Kerja Kementerian Negara Republik Indonesia;

8. Peraturan Presiden Nomor 24 Tahun 2006 tentang Kedudukan, Tugas dan Fungsi Eselon I Kementerian Negara;

9. Keputusan Menteri Agama Nomor 3 Tahun 1999 tentang Gerakan Keluarga Sakinah;

10. Keputusan Menteri Agama Nomor 480 Tahun 2008 tentang Perubahan Atas Keputusan Menteri Agama Nomor 373 Tahun 2002 tentang Organisasi dan Tata Kerja Kantor Wilayah Kementerian Agama Provinsi dan Kantor Departemen Agama Kabupaten/Kota;

11. Peraturan Menteri Agama Nomor 10 Tahun 2010 tentang Organisasi dan Tata Kerja Kementerian Agama;

12. Surat Edaran Menteri Dalam Negeri Nomor 400/54/III/Bangda perihal Pelaksanaan Pembinaan Keluarga Sakinah. ${ }^{11}$

Adapun materi yang diberikan mencakup tentang peraturan perundangundangan perkawinan, pelaksanaan fungsi keluarga, manajemen konflik dalam rumah tangga, merawat cinta kasih dalam keluarga, kesehatan reproduksi suami istri dan psikologi perkawinan dan keluarga. Sedangkan metode dalam memberikan materinya dapat dilakukan dengan ceramah, diskusi, tanya jawab dan penugasan yang pelaksanaanya disesuaikan dengan kondisi dan kebutuhan di lapangan, kemudian waktu untuk memberikan materi tersebut sekurang-kurangnya 16 (enam

11 Peraturan Direktur Jenderal Bimbingan Masyarakat Islam Nomor: DJ.II/542 Tahun 2013 tentang Pedoman Penyelenggaraan Kursus Pra Nikah. 
belas) jam pelajaran. Kemudian narasumbernya terdiri dari konsultan perkawinan dan keluarga, tokoh agama dan tokoh masyarakat yang memiliki kompetensi sesuai dengan keahliannya dalam materi-materi di atas. ${ }^{12}$

Dengan demikian, eksistensi kursus pra nikah tersebut secara historis dilatarbelakangi oleh fenomena rendahnya kualitas perkawinan yang terjadi di masyarakat. Karenanya, pemerintah berinisiatif untuk memberikan bekal kepada para mempelai agar memiliki pengetahuan terkait tatacara membangun rumah tangga dengan tujuan agar para mempelai dapat menciptakan kesejahteraan dalam kehidupan rumah tangganya.

\section{Relevansi Kursus Pra Nikah dengan Pembangunan Nasional}

Sebagaimana disebutkan di atas, bahwa saat ini keluarga menjadi salah satu isu tematik dalam pembangunan nasional. Maksud dijadikannya sebagai salah satu isu tersebut, karena pondasi pembangunan nasional bersumber dari unsur keluarga sebagai kelompok kecil dalam masyarakat. ${ }^{13}$ Artinya, keluarga di era saat ini memiliki peran yang sangat penting untuk mencapai keberhasilan pembangunan nasional. Peran penting yang ditopang keluarga tidak lain adalah bagaimana agar para suami dan istri dapat menciptakan kesejahteraan dalam kehidupan rumah tangganya, untuk mencapai kesejahteraan tersebut maka langkah pertama yang diperlukan adalah membentuk ketahanan keluarga.

Secara yuridis, sebagaimana dipaparkan oleh Badan Kependudukan dan Keluarga Berencana Nasional (BKKBN) bahwa dalam Undang-Undang Nomor 10 Tahun 1992 tentang Perkembangan Kependudukan dan Pembangunan Keluarga Sejahtera disebutkan bahwa ketahanan keluarga berfungsi sebagai alat untuk mengukur seberapa jauh keluarga telah melaksanakan peranan, fungsi, tugas-tugas dan tanggung jawabnya dalam mewujudkan kesejahteraan anggotanya. ${ }^{14}$ Adapun dimensi yang dapat menjadi ukuran dalam menciptakan ketahanan keluarga ialah: (1) landasan legalitas dan keutuhan keluarga, (2) ketahanan Fisik, (3) ketahanan ekonomi, (4) ketahanan sosial psikologi, (5) ketahanan sosial budaya. ${ }^{15}$

Kelima dimensi di atas merupakan suatu keniscayaan yang harus diupayakan oleh para individu (suami-istri), agar dapat membentuk ketahanan keluarga yang kemudian secara otomatis akan tercipta kesejahteraan dalam kehidupan keluarga. Sebagaimana Undang-Undang Nomor 52 Tahun 2009 mendefinisikan ketahanan dan kesejahteraan keluarga sebagai kondisi keluarga yang memiliki keuletan dan

12 Pasal 8 Peraturan Direktur Jenderal Bimbingan Masyarakat Islam Nomor: DJ.II/542 Tahun 2013 tentang Pedoman Penyelenggaraan Kursus Pra Nikah.

${ }^{13}$ Badan Pusat Statistik, Pembangunan Ketahanan Keluarga, (Jakarta: Kementerian Pemberdayaan Perempuan dan Perlindungan Anak, 2016), hlm. 1.

${ }^{14} \mathrm{Ibid}, \mathrm{hlm} .1$.

${ }^{15} \mathrm{Ibid}, \mathrm{hlm} .8$. 
ketangguhan serta mengandung kemampuan fisik materil guna hidup mandiri dan mengembangkan diri dan keluarganya untuk hidup harmonis dalam meningkatkan kesejahteraan kebahagiaan lahir dan batin. ${ }^{16}$ Oleh sebab itu, menciptakan ketahanan keluarga merupakan suatu yang penting untuk dilaksanakan, karena akan berakibat juga terhadap terjaminnya ketahanan masyarakat dan dapat meminimalisir atau mengendalikan berbagai kendala yang menghambat pembangunan nasional. Dengan demikian, keluarga merupakan salah satu kunci bagi keberhasilan pembangunan nasional.

Sebagai kunci pembangunan nasional, maka upaya untuk membentuk ketahanan keluarga merupakan suatu keniscayaan yang harus dilaksanakan. Salah satu upayanya, dapat dilakukan dengan menyelenggarakan kursus pra nikah kepada para calon mempelai. Sebagaimana dipaparkan oleh Khoiruddin Nasution bahwa kursus pra nikah memiliki peran yang sangat penting untuk membangun ketahanan keluarga, hal ini dikarenakan program tersebut menyampaikan pengetahuan kepada para calon mempelai seputar kehidupan berkeluarga dan tatacara yang bisa dilaksanakan untuk menghadapi masalah-masalah yang akan terjadi. ${ }^{17}$

Adapun kaitannya kursus pra nikah dengan pembangunan nasional, bisa dilihat dari materinya yang dapat membantu untuk mencapai keberhasilan pembangunan nasional, dalam konteks ini yaitu untuk menciptakan kesejahteraan dalam kehidupan keluarga. Materi tersebut pada dasarnya bertujuan agar para calon pengantin mengetahui apa saja yang harus disiapkan dalam membangun keluarga keluarga yang sejahtera. Hal ini penting, karena pondasi utama dari sebuah perkawinan yang berkualitas sangat bergantung pada kemampuan para calon mempelai dalam menjalani bahtera rumah tangganya kelak nanti.

Mendasarkan pada Peraturan Direktur Jenderal Bimbingan Masyarakat Islam tentang Kursus Calon Pengantin Nomor. DJ. II/491 Tahun 2009, materi tersebut diantaranya ialah: Pertama, Peraturan Perundang-Undangan yang di dalamnya terdiri dari Undang-Undangan Perkawinan (UUP), Kompilasi Hukum Islam (KHI), UndangUndang Kekerasan Dalam Rumah Tangga (UU KDRT) dan Undang-Undang Perlindungan Anak (UUPA).

Dalam UUP dan KHI para calon pengantin diberikan pemahaman tentang azas perkawinan, batas usia nikah, harta bersama serta hak dan kewajiban istri suami. Misalnya, pada batas usia perkawinan dijelaskan bahwa usia minimal perkawinan ialah 19 tahun baik bagi pria maupun wanita. Sedangkan menurut BKKBN idealnya usia perkawinan ialah 21 tahun untuk wanita dan 25 tahun untuk laki-laki. ${ }^{18}$

16 Pasal 1 Ayat (11) Undang-Undang Republik Indonesia Nomor 52 Tahun 2009 tentang Perkembangan Kependudukan dan Pembangunan Keluarga.

${ }_{17}$ Khoiruddin Nasution dan Syamruddin Nasution, Peraturan, hlm. 20.

${ }^{18}$ BKKN, Pendewasaan Usia Perkawinan dan Hak-Hak Reproduksi Bagi Remaja Indonesia, (Jakarta, 2018), hlm. 19 
Batasan usia tersebut dimaksudkan supaya para mempelai memiliki pengetahuan terhadap kesehatan reproduksi dan kehidupan berkeluarga. Karena, menikah di usia yang ideal akan memiliki kedewasaan dalam menghadapi masalahmasalah yang akan terjadi. Sedangkan menikah di usia yang ideal, kerap kali berujung pada ketidak harmonisan bahtera rumah tangga karena masih sering labil baik kejiwaan maupun emosinya dalam menyikapi masalah-masalah yang terjadi, sehingga mengakibatkan rawan terhadap perceraian. ${ }^{19}$

Selanjutnya UU KDRT, perlunya penyampaian materi ini karena ketika terjadi perselisihan dalam rumah tangga tidak jarang disertai dengan kekerasan baik secara fisik maupun psikis yang kemudian dapat memicu terjadinya perceraian. ${ }^{20}$ Karenanya, para calon pengantin agar menghindari tindakan tersebut. Selain itu, dalam UUPA para calon pengantin diberikan pengetahuan seputar kewajiban dan tanggung jawabnya orang tua untuk mengasuh, memelihara, mendidik dan melindungi anak, menumbuhkembangkan anak sesuai dengan kemampuan, bakat dan minatnya dan mencegah terjadinya perkawinan pada usia anak-anak. ${ }^{21}$

Kedua, ekonomi. Pada umumnya, fenomena tingginya angka perceraian yang terjadi di masyarakat disebabkan oleh faktor ekonomi..22 Karenanya, sebelum melakukan perkawinan para calon pengantin harus memiliki kesiapan secara ekonomi terlebih dahulu. Jika para calon pengantin sudah memiliki kesiapan ekonomi, maka dalam membentuk keluarga para calon pengantin memiliki sumber daya untuk keberlangsungan hidupnya. Namun, apabila sebaliknya maka dikhawatirkan keberlangsungan kehidupan rumah tangganya rawan terjadi pertengkaran dan kemudian berujung pada perceraian. Karena, ekonomi sebagai salah satu faktor yang dapat mempengaruhi kesejahteraan dalam kehidupan keluarga. ${ }^{23}$

Ketiga, kesiapan fisik. Dalam hal ini yaitu kesiapan secara biologis, seperti kesiapan organ tubuh untuk melakukan reproduksi dan hubungan seksual yang sehat. Pentingnya kesiapan fisik ini, karena jika salah satu dari keduanya belum

19 Sulaiman, Dominasi Tradisi dalam Perkawinan di Bawah Umur, Analisa, Vol. 19, No. 1, Juni 2012, hlm. 23.

${ }^{20}$ Dian Ety Mayasari, Tinjauan Yuridis Adanya Kekerasan Dalam Rumah Tangga Sebagai Alasan untuk Melakukan Perceraian, Mimbar Hukum, Vol. 25, No. 3, Oktober 2013, hlm. 434.

${ }^{21}$ Pasal 26 Ayat (1) Undang-Undang Nomor 23 Tahun 2003 tentang Perlindungan Anak.

${ }_{22}$ Abdul Thalib dan Meilan Lestari, Tingginya Tingkat Gugat Cerai di Pengadilan Agama Pekanbaru, Vol. XVII, No. 1, Juni 2017, hlm. 32. Lihat Juga, Syaefullah dan Nurmahmudah, Analysis of Causing Factors Divorce in Indramayu District 2018 (Case Study in the Religion Court of Indramayu District in 2018), ahakim, Vol. II, No. 2, Juni 2018, hlm. 86.

${ }^{23}$ Aulia Rizki Akbar, Akhirmen dan Mike Triani, Faktor-Faktor yang Mempengaruhi Kesejahteraan Keluarga di Sumatera Barat, EcoGen, Vol. 1, No. 3, September 2018, hlm. 531. 
memiliki kesiapan fisik khususnya pada perempuan, maka akan dapat berpengaruh terhadap kesehatan janin yang dikandungnya kelak nanti. ${ }^{24}$

Keempat, psikologi keluarga. Perlunya pembekalan ini disebabkan kesiapan psikologis masing-masing individu sangat berpengaruh untuk menjaga keharmonisan rumah tangganya. Jika para calon pengantin memiliki kesiapan tersebut, maka apapun masalah yang terjadi dalam rumah tangganya mereka akan mampu mengendalikannya secara dewasa, disikapi dengan tenang dan bertanggung jawab. 25

Kelima, cinta kasih dalam keluarga. Tujuan dari diberikan materi ini agar para calon pengantin memiliki kompetensi untuk berinteraksi, sebagaimana istri dan suami wajib untuk saling mendengarkan, menghargai bila terjadi perbedaan dan membahas masalah pribadi dengan pasangan. ${ }^{26}$ Apabila para calon pengantin memiliki kesiapan ini dengan baik, maka akan saling dapat memahami, memperdulikan dan menghargai satu sama lainnya, sehingga dapat saling menjaga keharmonisan dan kesejahteraan dalam kehidupan keluarganya. Sebaliknya, jika tidak memiliki kesiapan tersebut maka dalam berumah tangga akan mudah terjadi konflik, sebab tidak adanya sifat untuk saling mengerti serta memperdulikan satu sama lainnya.

Keenam, keterampilan hidup. Diberikannya pengetahuan tentang keterampilan hidup diharapkan agar calon pengantin dapat mengembangkan kemampuannya dalam berbagai kapasitasnya untuk memenuhi peran dan fungsinya dalam berkeluarga. Dengan mempersiapkan keterampilannya maka para calon pengantin akan dapat bekerjasama dalam menyelesaikan pekerjaan rumah tangganya. ${ }^{27}$ Tentu, apabila sebaliknya para calon pengantin tidak mempersiapkan keterampilannya dengan baik maka akan mendapat kesulitan dalam menjalankan perannya.

Ketujuh, pendidikan dan nilai. Maksud diberikannya pengetahuan tentang pendidikan dan nilai dalam hal ini yaitu moral, para calon pengantin diharapkan mampu untuk mengerti tentang nilai-nilai kehidupan yang baik seperti ketaatan, memaafkan dan kesabaran. Nilai-nilai tersebut penting untuk dipahami, karena dapat

${ }^{24}$ Miswanto.Pentingnya Pendidikan Kesehatan Reproduksi dan Seksualitas pada Remaja, Jurnal Studi Pemuda, Vol. 3, No. 2, September 2014, hlm. 115.

${ }^{25}$ Danu Aris Setiyanto, Konstruksi Pembangunan Hukum Keluarga di Indonesia Melalui Pendekatan Psikologi, Al-Ahkam, Vol. 27, No. 1, April 2017, hlm. 36.

${ }^{26}$ Radhiya Bustan, Persepsi Dewasa Awal Mengenai Kursus Pranikah, Jurnal Al-Azhar Indonesia, Vol. 3, No. 1, Maret 2015, hlm. 87.

${ }^{27}$ Adi Fahrudin, Keberfungsian Keluarga: Konsep dan Indikator Pengukuran dalam Penelitian, Informasi, Vol. 17, No. 2, 2012, hlm. 77. 
menjadi pedoman dan prinsip dalam menjalankan kehidupannya. ${ }^{28}$ Para calon pengantin yang sudah mempersiapkan moralnya dengan baik diharapkan dapat bertindak secara bijak sehingga dapat saling mematuhi, menghargai dan menjaga komitmen bersama.

Kedelapan, kesiapan intelektual. Maksudnya yaitu kemampuan para calon pengantin dalam berfikir dan senantiasa mencari berbagai ilmu yang bermanfaat bagi kehidupan pribadi dan keluargannya. Kesiapan intelektual tersebut sangat diperlukan oleh para calon pengantin untuk menggali pengetahuan tentang kehidupan berkeluarga, seperti tata cara mengelola sumber daya keluarga dan lainnya. ${ }^{29}$ Sehingga bila terjadi permasalahan dalam rumah tangga para calon pengantin akan dapat mengatasi dan mencari solusinya dengan bijak.

Kesembilan, sosial. Diberikannya materi tentang kesiapan sosial ini, diharapkan bagi para calon pengantin untuk memahami bahwa nilai-nilai dalam keluarga merupakan cerminan dari nilai-nilai masyarakat. Selain itu, para calon pengantin juga diharapkan dalam menjaga keharmonisannya tidak hanya dalam rumah tangganya saja, akan tetapi interaksi dengan masyarakat sekelilingnya seperti kerabat dekat, tetangga dan kelompok sosial lainnya juga harus dijaga. Karena, dengan memiliki hubungan baik terhadap lingkungan sekitar dapat berpengaruh terhadap kelanggengan keharmonisan rumah tangganya. ${ }^{30}$

Berdasarkan materi kursus pra nikah di atas, maka dapat penulis katakan bahwa dengan diberikannya materi tersebut diharapkan agar para calon pengantin mempunyai pengetahuan untuk membangun kehidupan keluarga yang sejahtera. Dengan demikian, kursus pra nikah dapat menjadi salah satu upaya untuk mencapai keberhasilan pembangunan nasional. Namun, dalam materi kursus pra nikah tersebut secara eksplisit terdapat materi yang belum merepresentasikan tentang kemitraan gender, kesetaraan gender hanya disampaikan secara implisit yaitu dalam bentuk materi tentang tugas suami dan istri dalam rumah tangga. ${ }^{31}$ Sebagaimana disebutkan dalam pembangunan ketahanan keluarga bahwa salah satu variabelnya

${ }^{28}$ Ilham Hudi, Pengaruh Pengetahuan Moral terhadap Perilaku Moral Pada Siswa SMP Negeri Kota Pekanbaru Berdasarkan Pendidikan Orang Tua, Jurnal Moral Kemasyarakatan, Vol. 2, No. 1, Juni 2017, hlm. 33.

${ }^{29}$ Yunita Syepriana, Firdaus Wahyudi dan Ari Budi Himawan, Gambaran Karakteristik Kesiapan Menikah dan Fungsi Keluarga pada Ibu Hamil Usia Muda, Jurnal Kedokteran Diponegoro, Vol. 7, No. 2, Mei 2018, hlm. 942.

${ }^{30}$ Leis Yigibalom, Peranan Interaksi Anggota Keluarga dalam Upaya Mempertahankan Harmonisasi Kehidupan Keluuarga di Desa Kumuluk Kecamatan Tiom Kabupaten Lanny Jaya, Journal, Vol. II, No. 4, 2013, hlm. 298. Lihat Juga, Eny Fatimatuszuhro Pahlawati, Pengaruh Keharmonisan Keluarga Terhadap Sikap Sosial Anak, Sumbula, Vol. 4, No. 2, Desember 2019, hlm. 298.

${ }^{31}$ Nurhasanah Bakhtiar dkk, Konseling Pranikah Berperspektif Gender pada Lembaga (BP4) untuk Menurunkan Tingkat Perceraian, Marwah, Vol. 17, No. 2, 2018, hlm. 157. 
adalah kemitraan gender. ${ }^{32}$ Selain itu, dalam pembangunan nasional juga salah satu target yang ingin dicapai ialah kesetaraan dan keadilan gender. ${ }^{33}$

Oleh sebab itu, menyertakan materi tentang kemitraan gender secara khusus merupakan suatu yang tidak dapat ditinggalkan. Karena, dengan terdapatnya kemitraan gender dalam kehidupan rumah tangga, dapat memperkuat ketahanan keluarga. Dengan demikian, maka kursus pra nikah tersebut semakin penting eksistensinya sebagai salah satu upaya untuk mencapai keberhasilan pembangunan nasional melalui ketahanan keluarga.

\section{Kesimpulan}

Berdasarkan uraian di atas, dapat penulis tarik kesimpulan bahwa di era modern saat ini keluarga memiliki peran yang sangat penting untuk mencapai keberhasilan pembangunan nasional. Hal ini disebabkan, dalam pembangunan nasional tersebut salah satu yang menjadi isunya adalah keluarga. Karenanya, menciptakan kehidupan keluarga yang sejahtera merupakan suatu keniscayaan yang harus dilakukan. Salah satu upaya untuk menciptakan keluarga yang sejahtera tersebut, dapat dilakukan dengan menyelenggarakan kursus pra nikah.

Selain itu, dilihat dari materi yang diberikan, maka kursus pra nikah ini memiliki relevansinya dengan pembangunan nasional melalui pembangunan ketahanan keluarga. Namun, masih ada materi yang secara eksplisit tidak dicantummkan dalam kursus pra nikah, yaitu materi tentang kemitraan gender. Padahal upaya yang dilakukan dalam rangka membentuk ketahanan keluarga tersebut, salah satu variabelnya adalah kemitraan gender. Oleh karenanya, penulis melihat bahwa perlu untuk menambahkan materi tentang kemitraan gender dalam materi kursus pra nikah tersebut.

\section{Daftar Pustaka}

Afrizal, Implementasi Kursus Pra Nikah dalam Mengurangi Angka Perceraian di KUA Pringsewu, Ijtimaiyyah: Jurnal Pengembangan Masyarakat Islam, Vol. 10, No. 1, 2017.

Akbar, Aulia Rizki, Akhirmen dan Mike Triani, Faktor-Faktor yang Mempengaruhi Kesejahteraan Keluarga di Sumatera Barat, EcoGen, Vol. 1, No. 3, September 2018.

Aris, Danu Setiyanto, Konstruksi Pembangunan Hukum Keluarga di Indonesia Melalui Pendekatan Psikologi, Al-Ahkam, Vol. 27, No. 1, April 2017.

Badan Pusat Statistik, Pembangunan Ketahanan Keluarga, Jakarta: Kementrian Pemberdayaan Perempuan dan Perlindungan Anak, 2016.

32 Badan Pusat Statistik, Pembangunan, hlm. 14.

33 Ratih Probosiwi, Perempuan dan Perannya dalam Pembangunan Kesejahteraan Sosial, NATAPRAJA, Vol. 3, No. 1, Mei 2015, hlm. 52. 
Bakhtiar, Nurhasanah, Mainizar, Raja Rahima MRA, Hasgimianti dan Irawati, Konseling Pranikah Berperspektif Gender pada Lembaga (BP4) untuk Menurunkan Tingkat Perceraian, Marwah: Jurnal Perempuan, Agama dan Jender, Vol. 17, No. 2, 2018.

BKKBN, Pendewasaan Usia Perkawinan dan Hak-Hak Reproduksi Bagi Remaja Indonesia, Jakarta, 2018.

Bustan, Radhiya, Persepsi Dewasa Awal Mengenai Kursus Pranikah, Jurnal Al-Azhar Indonesia, Vol. 3, No. 1, Maret 2015.

Ety, Dian Mayasari, Tinjauan Yuridis Adanya Kekerasan Dalam Rumah Tangga sebagai Alasan untuk Melakukan Perceraian, Mimbar Hukum, Vol. 25, No. 3, Oktober 2013.

Fahrudin, Adi, Keberfungsian Keluarga: Konsep dan Indikator Pengukuran dalam Penelitian, Informasi, Vol. 17, No. 2, 2012.

Fatimatuszuhro, Eny Pahlawati, Pengaruh Keharmonisan Keluarga Terhadap Sikap Sosial Anak, Sumbula, Vol. 4, No. 2, Desember 2019.

Hudi, Ilham, Pengaruh Pengetahuan Moral Terhadap Perilaku Moral Pada Siswa SMP Negeri Kota Pekanbaru Berdasarkan Pendidikan Orang Tua, Jurnal Moral Kemasyarakatan, Vol. 2, No. 1, Juni 2017.

Iskandar, Zakyyah, Peran Kursus Pra Nikah dalam Mempersiapkan Pasangan Suami-Istri Menuju Keluarga Sakinah, Al-Ahwal, Vol. 10, No. 1, Juni 2017.

Miswanto, Pentingnya Pendidikan Kesehatan Reproduksi dan Seksualitas Pada Remaja, Jurnal Studi Pemuda, Vol. 3, No. 2, September 2014.

Nasution, Khoiruddin, Syamruddin Nasution, Peraturan dan Program Membangun Ketahanan Keluarga: Kajian Sejarah Hukum, Asy-Syir'ah, Vol. 51, No. 1, Juni 2017.

Peraturan Direktur Jenderal Bimbingan Masyarakat Islam Nomor: DJ.II/542 Tahun 2013 tentang Pedoman Penyelenggaraan Kursus Pra Nikah.

Peraturan Pemerintah Republik Indonesia Nomor 21 Tahun 1994 tentang Penyelenggaraan Pembangunan Keluarga Sejahtera.

Probosiwi, Ratih, Perempuan dan Perannya dalam Pembangunan Kesejahteraan Sosial, NATAPRAJA, Vol. 3, No. 1, Mei 2015.

Saefullah dan Nurmahmudah, Analysis of Causing Factors Divorce in Indramayu District 2018 (Case Study in the Religion Court of Indramayu District in 2018), ahakim, Vol. II, No. 2, Juni 2018.

Sulaiman, Dominasi Tradisi Perkawinan di Bawah Umur, Analisa, Vol. 19 No. 1, Juni 2012.

Syepriana, Yunita, Firdaus Wahyudi dan Ari Budi Himawan, Gambaran Karakteristik Kesiapan Menikah dan Fungsi Keluarga pada Ibu Hamil Usia Muda, Jurnal Kedokteran Diponegoro, Vol. 7, No. 2, Mei 2018. 
Thalib, Abdul dan Meilan Lestari, Tingginya Tingkat Gugat Cerai Di Pengadilan Agama Pekanbaru, Hukum Islam, Vol. XVII, No. 1, Juni 2017.

Undang-Undang Republik Indonesia Nomor 23 Tahun 2003 tentang Perlindungan Anak.

Undang-Undang Republik Indonesia Nomor 52 Tahun 2009 tentang Perkembangan Kependudukan dan Pembangunan Keluarga.

Yigibalom, Leis, Peranan Interaksi Anggota Keluarga Dalam Upaya Mempertahankan Harmonisasi Kehidupan Keluarga Di Desa Kemuluk Kecamatan Tiom Kabupaten Lanny Jaya, Journal, Vol. II, No. 4, 2013. 